\title{
Vestidos e descalços: Uma arqueologia da visualidade na fotografia de escravos do Brasil do século XIX
}

Resumo

O presente artigo objetiva pensar a imagem a partir de uma experiência de análise com fotografia, na busca por construir uma história visual sobre uma possível experiência escrava no Brasil do século XIX. Trata-se de uma história visual do social que se atenta para dimensões "menores" da imagem fotográfica e expressa tramas, relações de poder, processos de constituição de sujeitos e a invenção do passado. 


\section{DRESSED AND BAREFOOTED: AN ARCHAEOLOGY OF VISUALITY IN 19th CENTURY SLAVES PHOTOGRAPHY IN BRAZIL}

\section{THIAGO F. SANT'ANNA \\ ANA CAROLINA CUSTÓDIO}

\section{Abstract}

This article proposes at thinking the image from an experience of analysis with photography e in the search for building a visual history about a possible slave experience in nineteenth-century Brazil. It is a visual history of the social that looks at "minor" dimensions of the photographic image and expressed plots, power relations, processes of constitution of subjects and the invention of the past. 


\section{Vestidos y Descalzos: Una Arqueología de la Visualidad en la Fotografía de Es- clavos de Brasil del siglo XIX}

\section{THIAGO F. SANT'ANNA \\ ANA CAROLINA CUSTÓDIO}

\section{Resumen}

El presente artículo objetiva pensar la imagen a partir de una experiencia de análisis con fotografía, en la búsqueda de construir una historia visual sobre una posible experiencia esclava en el Brasil del siglo XIX. Se trata de una historia visual de lo social que se atenta hacia dimensiones "menores" de la imagen fotográfica y expresa tramas, relaciones de poder, procesos de constitución de sujetos y la invención del pasado. 
A ordem privada escravista. O homem branco é o senhor, dono, proprietário dos cinco outros homens negros e mulatos. Está na frente, na posição de autoridade e domínio. Os outros se encontram atrás. $\mathrm{O}$ primeiro à esquerda do senhor é mulato, está bem vestido. Ao contrário dos outros, deixou o cabelo meio liso crescer, penteou-o, fez uma risca do lado esquerdo, como o seu senhor. Mas não pode usar sapatos, privilégio e marca distintiva dos livres e libertos. Tirar fotografia era uma operação demorada. Ninguém podia se mexer durante quase dois minutos. Outras tentativas já podiam ter falhado. O fotógrafo Militão, que fez essa foto em São Paulo, deve ter reclamado. Por isso ou por outras razões mais secretas, o senhor está zangado, de cara amarrada. $\mathrm{O}$ escravo situado à direita, assustado, encolheu-se. Na extrema esquerda, o homem com a varinha na mão - pastor de cabras ou de vaca leiteira na cidade - tem um olhar altivo, talvez porque traga nas mãos o objeto de seu ofício, que o distingue dos outros cativos, paus para toda obra. Na extrema direita, o homem de branco se mexeu: estragou a foto na ordem escravista programada pelo seu senhor. Vai apanhar. No seu rosto fora de foco vislumbra-se o medo. Vai apanhar. (ALENCASTRO, 2002, p. 18).

Elucidativas as palavras de Alencastro no seu comentário sobre a ordem privada escravista no Brasil, especificamente no Rio de Janeiro do século XIX, capazes de deixar qualquer espectador a contemplar por um tempo essa fotografia, quase como se mil palavras coubessem na imagem. Interpretar representações, traduzir os significados, descortinar intenções, assim como prever um futuro, podem ser estratégias metodológicas por meio das quais palavras e imagens suscitam múltiplas leituras da experiência humana, diga-se de passagem, incapturáveis por uma versão final. Uma imagem fotográfica representaria os fatos de forma semelhante ao que realmente aconteceu? Descortinaria significados escondidos com semântica profunda que estaria asilada nas folhagens de uma superfície visual? Revelar-nos-ia a fotografia, as intenções do fotógrafo Militão Augusto de Azevedo que a produziu ou do proprietário dos escravos? Designaria sentidos? Que maneiras de dizer poderiam conduzir-nos a falar sobre essa imagem fotográfica? Seriam as palavras perigosas? Seriam as imagens ameaçadoras? São respostas tão distantes quanto as palavras das imagens e não poderíamos nos furtar a uma arqueologia da visualidade inspirada em Foucault (2000a, p. 12), quando
Fonte: ALENCASTRO, Luiz Felipe de. Vida Privada e Ordem Privada no Império. In: ALENCASTRO, Luiz Felipe de. História da Vida Privada no Brasil. Império: a corte e a modernidade nacional. São Paulo: Companhia das Letras, 2002. O banco de dados consultado por Alencastro foi: KOSSOY, Boris; TUCCI CARNEIRO, M. Luiza. O olhar europeu: o negro na iconografia brasileira do século XIX. São Paulo, 1994. 
ele analisou o quadro Las Meninas em "As Palavras e as Coisas", e destacou a sua abordagem:

[...] por mais que se diga o que se vê, o que se vê não se aloja jamais no que se diz, e por mais que se faça ver o que se está dizendo por imagens, metáforas, comparações, o lugar onde estas resplandecem não é aquele que os olhos descortinam, mas aquele que as sucessões da sintaxe definem.

Recusar relações de semelhança e de identidade entre o dito e o visual é uma estratégia de incursão tanto ao campo da imagem quanto da analítica foucaultiana, sendo por meio delas que construímos uma tática de tomar ideias do filósofo as quais possam sinalizar possíveis relações na imagem fotográfica, as quais, talvez, não estejam tão próximas das palavras de Alencastro, mas seguramente distantes do que o fotógrafo realmente queria nos mostrar. Abrir mão de relações de causalidade, entre certa representação da imagem e certa estrutura já dada, permanente e imóvel e, porque não dizer, responsável por um processo a-histórico de constituição da realidade, no campo da História Visual e dos Estudos de Cultura Visual, nos coloca diante de alguns desafios, pois não há como negar as dimensões da relação conflituosa entre o mundo das "sagradas escrituras" e o mundo dos adoradores das imagens (FLUSSER, 2002). Disfarçados de idólatras, porque traidores e profanadores de dispositivos (AGAMBEN, 2009) que somos diante das fontes visuais, operamos parte de um "olhar circular", de que fala Flusser (2002, p. 8), onde "um elemento é visto após o outro", aonde tendemos a "voltar para contemplar elementos já vistos", onde um "antes" se torna "depois" e o "depois" se torna "antes". Um olhar atento aos detalhes, às relações possíveis de serem tecidas, como se a fotografia fosse um feixe de relações a ser não traduzido, mas construído como mapa de objetos, como um rizoma de conexões onde se articulam visibilidades, práticas, técnicas. É um mapa de visibilidades não isoladas, mas coexistem sem uma organização prévia, tecidas no mesmo movimento em que as olhamos enquanto elas também nos olham. A fotografia é como uma rede de conexões onde "qualquer ponto de um rizoma pode ser conectado a qualquer outro" (DELEUZE; GUATARRI, 2011, p. 22). Trata-se de uma coexistência de relações cravadas, constituídas e constitutivas de um saber visual, em relação à qual qualquer "eterno retorno" de que fala Alencastro ou Flusser não é um retorno ao "mesmo", e, 
sim, ao "diferente" (MACHADO, 2009, p. 185), na busca por destruir os pretensiosos vínculos entre a diferença e a repetição com o referente, através da identidade (DELEUZE, 200o).

O suporte material - a fotografia - cuja luz forma visibilidades em uma imagem fotográfica, distribuindo tonalidades, opacidades, o visto e o não visto, leva-nos, heraclitianamente, a nunca observar as imagens com os mesmos olhos. Ao contrário, somos instigados à construção de uma "história do possível" que recuse tradições, certezas e evidências, e também ao "frescor da multiplicidade, a pluralidade do real", segundo Navarro-Swain (2006), que nos estimule a trair os nossos próprios olhos quando recusamos a busca por uma relação de semelhança entre o original e as infindáveis leituras possíveis que forjam outras histórias, as quais datam outros tempos, que produzem e inventam referentes para serem pensados como anteriores ao momento do registro fotográfico. Trata-se de uma perspectiva de história que, pensada por Navarro-Swain (2006, on-line), busca "incansavelmente a diversidade para escapar à tirania do unívoco, do homogêneo, da monótona repetição do mesmo". Dessa forma, sem idolatrar as palavras de Alencastro, mas delas nos aproximarmos para abordar as relações entre olhares e imagens que nos são dadas a ver, podemos somar a essas outra estratégia metodológica por nós empreendida: que é a de um artesão que, no processo de fabricação de novas peças, fabrica e modifica suas próprias ferramentas, já que os sentidos ${ }^{1}$ não existem fora dos procedimentos que os estabelecem.

As nuances de preto e branco, na fotografia, permitem-nos identificar uma primeira tentativa da imagem flechar o espectador - o punctum de Barthes (1984) - na busca por separar os lugares dos negros e o lugar do branco. Cores e lugares são signos com posições visuais que produzem efeitos de sentidos. Enrolado no signo, o sentido nos coage a pensar (MACHADO, 2009) sobre o centro e o primeiro plano da imagem, dando-nos a ver o foco que enquadra, segundo a leitura Alencastro, o proprietário dos escravos. O segundo plano e a decorrente distribuição espacial em direção às extremidades da imagem - que permite aos nossos olhares percorrer até o personagem desfocado - é preenchido por pessoas, homens, negros, muito provavelmente, escravos, propriedades daquele que ocupa um lugar de onde emana um tipo de exercício de poder. Posições e condições raciais, conforme a leitura de Alencastro, sinalizam a relação entre certa descrição da fotografia e as possíveis condições não-discursivas que situam 
processos socioeconômicos de realidades no Brasil do século XIX. Problematizemos esse sujeito "já feito", originário e fundador, pelo viés da leitura de Alencastro: em que condições as visualidades constituem sujeitos? Como a imagem fotográfica, enquanto "arquivo visual" cujas visibilidades "nem são ocultas, nem imediatamente visíveis" (MACHADO, 2009, p. 165-166), "sub-jaz" aos sujeitos (FISCHER, 2012, p. 42)?

$\mathrm{Na}$ busca por atingir certas condições que tornam "visibilidades visíveis", já que uma formação visual e sócio-histórica pode ser apresentada pelo que "vê" (MACHADO, 2009, p. 166), nem sempre redutível ao que "diz", essas possíveis relações que a fotografia arquiva perfazem o desenho de um mapa por meio do qual o poder, operado como relação de forças, difuso, instável, localizável em pontos singulares, atravessa e torna possível modos de ver. Trata-se de um foco indispensável para aqueles/as que se interessam pelo campo dos Estudos de Cultura Visual, compreendido como "um domínio específico de pesquisa, cujos princípios e problemas fundamentais" têm como objetivo analisar a construção social do visual e a construção visual do social (MITCHELL apud DIKOVITSKAYA, 2006, p. 58; KNAUSS, 2006, p. 108). Inscritos em fronteiras permeáveis, o social e o visual, sob a ótica da nossa análise, voltada para o exercício, destacam modos de ver na história e também forjam uma construção visual possível de uma história, de uma sociedade marcada por diferenças sociais inscritas no visual (DIKOVITSKAYA, 2006). Os Estudos de Cultura Visual, ao destruirem os liames naturais entre as imagens e as coisas, buscam, deste modo, "rasgar o véu da familiaridade e despertar o sentido do maravilhoso" (MITCHELL, 2002, p. 179). Em outras palavras, Dikovitskaya assinala que os estudos visuais, nascidos da aglomeração da História da Arte aos Estudos Culturais, articulam imaginário, memória e fantasia em "uma área de investigação e uma iniciativa curricular que apreendem o visual como foco no processo através do qual o sentido é construído no interior de um contexto cultural" (DIKOVITSKAYA, 2006, p. 1).

Munidos de uma inspiração ancorada no referencial dos Estudos de Cultura Visual, podemos perceber relações que dão visibilidade a posições sob as quais localizamos o funcionamento do poder micropolítico como rede de relações e condições de exercício de que fala Foucault (2001), capaz de atravessar os confins da intimidade e diluir as fronteiras entre público e privado. Seria alguém portador desse poder? Destaquemos o seu funcionamento através do exercício de um po- 
der que emana das imponentes posições que assumem tanto proprietários quanto escravos na busca por tecer relações de visualidades entre os próximos e os distantes do lugar ocupado pelo proprietário. Trata-se de visibilidades possíveis, ao passo que outras visibilidades dizem respeito às relações de poder. Vejamos como elas operam!

A descrição de Alencastro é clara no seu direcionamento: o lugar do proprietário é um lugar do soberano, que detém o poder, ao passo que os lugares dos escravos são de pessoas desprovidas de qualquer poder. A negritude ou a mulatez dos escravos, as vestimentas e o penteado do cabelo, os pés descalços e o objeto do ofício e, por último, o futuro do escravo que vai apanhar porque se mexeu durante o tempo de captação da imagem, não tem nuance alguma, mas revela-nos a captura em um dispositivo que é a construção discursiva homogeneizante e universal que abrange o conceito de escravo, desprovido de poder, em contraposição à cara zangada e amarrada do todo-poderoso senhor de escravos. Alencastro separa, portanto, os fortes e os fracos, os que possuem o poder e os que dele estão destituídos.

Convidemos agora o leitor para percorrer outros caminhos por uma arqueologia da visualidade que observe a intervisualidade que atravessa a distribuição de inúmeras imagens que existem dentro da imagem fotográfica. Longe de ser a imagem em questão uma totalidade fechada, os seus detalhes podem ser destacados, possibilitando-nos tornar o visível - o que se dá a ver (MENESES, 2005) -, visível, e o visualizável - a "rede de imagens" que produzem "imagens de referência, recorrentes, catalisadoras, identitárias" (MENESES, 2005, p. 35) -, visualizável, de forma a fazer o jogo das entonações imagéticas (VEIGA-NETO, 2004). As imagens dentro da imagem são visibilidades dispersas, esmaecidas na frágil unidade sugerida pela fotografia, em que emergem, e que as delimita, especifica e produz objetos visuais a partir dos quais é possível construir histórias visuais possíveis.

Cabe aqui uma operação empreendedora de fissuras e suturas, na busca por forjar uma ferramenta interpretativa, informados de que estamos sobre o exercício criativo da análise. Trata-se de uma ferramenta arqueológica a ser operada e fabricada em um mesmo movimento em que é exumada. A alusão a Rouillé (2009, p. 19) é uma escolha para quem "entre o real e a imagem sempre se interpõe uma série infinita de outras imagens, invisíveis, porém operantes, que se constituem em um saber visual, em prescrições icônicas, em 
esquemas estéticos". Trata-se de uma rede de experiências intervisuais onde a atenção para os detalhes nos remete a uma costura com o empreendimento arqueológico de Foucault, para quem partimos dos detalhes aos quais é dado destaque, remetendo-nos também a imagens mergulhadas dentro da imagem. Abordamos a fotografia a partir de outra ferramenta, concepção de monumento de que fala Foucault (2000a), a ser atribuída à fonte em questão, passível de ser trabalhada no interior e elaborada, organizada, recortada, repartida em níveis, a estabelecer séries e propor pertinências, identificar elementos, definir unidades e descrever relações. Tal costura implica uma escolha que recusa qualquer sonho em busca da obtenção da verdade e da sinceridade e que marca a falsidade e a alteração.

\section{Vestimentas que separam e pés descalços que aproximam}

Percorramos a imagem dos pés às cabeças! Na imagem, não há mobiliário, joias e nem quadros que componham o cenário da fotografia, apenas um painel pintado, ao fundo, compondo a cena de um homem branco à frente, provavelmente proprietário dos escravizados. Conforme Koutsoukos (2006, p. 98), essa era uma das formas de um senhor de escravos "mostrar a sua riqueza e, principalmente, o seu poder", relacionado à posse e baseado no exercício da humilhação que impinge a seus servos. A pose do homem que ocupa a posição de dono de outros homens, com o seu olhar austero, é também a pose que ocupa uma posição social de que opera e exercita um poder. Os símbolos de distinção social também estão presentes no seu corpo e indumentária, constituída aquela por um paletó de tonalidade escura, uma peça de roupa de tonalidade clara por baixo, uma gravata borboleta e calças de tonalidade escuras e sapatos um pouco mais claros. O rosto, uma das imagens do corpo, é decorado por uma barba e cabelos lustrados e penteados. A gravata sempre preta e de cetim, assim como o paletó, são alguns dos sinais exteriores - esses elementos, como paletó, gravata e sapatos demonstravam o apego aos símbolos fálicos e aos de derivação da elegância - que informavam aos outros o lugar que se ocupava na sociedade. Eram formas sutis de afirmação social e prestígio (SOUZA, 1987).

Atrás do senhor, cinco homens escravizados, juridicamente constituídos como escravos, são retratados por Militão Augusto de Azevedo. O primeiro (à esquerda) com pose 
muito próxima à do seu proprietário, com a cabeça erguida e mãos cruzadas à frente do quadril, traja com uma camisa de tonalidade escura, com partes levemente amarrotadas e nuances mais claras, o que poderia ser um indicativo de desgaste da peça. Desgaste este que pode ter sido ocasionado pela exposição ao sol no exercício das suas atividades laborais e servis, talvez sinalizadas pela vara presa entre as mãos a qual, tudo indica é seu instrumento de trabalho, relacionado provavelmente à atividade de "pastorear cabras ou vacas" (KOUTSOUKOS, 2006, p. 98). Ele também veste uma calça comprida também de tonalidade escura, e segura um chapéu. Seu rosto apresenta uma farta barba e cabelos à mostra. É retratado de pés descalços, mais uma indicação de sua condição escrava e, em oposição a seu proprietário, que calça botas, uma reafirmação da posição social deste senhor, que se coloca imponentemente à frente.

O segundo homem escravizado traz uma camisa de tonalidade escura, com tecido amarrotado, tendo, por baixo, outra peça de cor mais clara. Usa também calça comprida, de tonalidade clara e, assim como o homem descrito anteriormente, também é retratado com os pés descalços. A barba densa e os cabelos à mostra conferiam singularidade à sua imagem.

O terceiro escravo exibe cabelos penteados e um rosto sem barba. Parte de sua vestimenta está encoberta pela imagem do seu senhor. $\mathrm{O}$ pouco que nosso olhar consegue ver indica-nos que ele veste uma camisa de tonalidade clara, com uma espécie de colete de cor escura e calças compridas de tonalidades claras e o tecido amarrotado. Seus pés também estão descalços.

Já o quarto homem escravizado veste-se com uma camisa de manga longa de cor escura que apresenta, assim como a do primeiro, algumas nuances claras em determinadas partes. Indício de um possível desgaste em suas roupas? Possivelmente. Levando em consideração as intensas atividades servis que os escravizados desempenhavam, assim como a má qualidade dos tecidos das vestes que os senhores lhes forneciam, é comum notarmos nos registros fotográficos peças com sinais de desgastes e remendos (MATTOSO, 2001). As suas calças compridas têm uma tonalidade escura e, diferentemente dos demais, traz uma alça que passa transversalmente pelo seu tronco embora não seja possível identificar sua função devido à qualidade da imagem. Seu rosto apresenta uma barba rala, os cabelos estão à mostra e, semelhantemente aos demais, seus pés estão descalços. 
Um quinto e último homem escravizado apresenta uma expressão visual de si (SANT'ANNA, 2013) forjadora de sujeitos e subjetividades, mais distinta que os outros ao levar a mão à boca. Talvez esse tenha sido um gesto de curiosidade em relação ao que estava acontecendo durante a captura daquela imagem e essa movimentação tenha causado esse leve borrão e efeito de desfoque em sua silhueta. Suas vestimentas são formadas por uma camisa de manga longa de tonalidade clara, sem manchas, uma calça comprida também de cor clara e levemente amarrotada. Na sua cintura, há uma espécie de faixa ou talvez cinto. Com a mão direita, ele segura um objeto de cor clara na altura dos quadris. Talvez um chapéu. Assim como os outros quatros homens escravizados, também é retratado com os pés descalços.

A disparidade entre as vestimentas do senhor e de seus escravizados, com a oposição entre tecidos engomados e gravatas, nuances de desgastes e peças amarrotadas ficam para nós, bem evidente após a descrição das vestimentas. As práticas de vestir produzem, singularmente, marcas e posições de sujeitos distantes e desiguais nas relações de poder entre homens livres e homens escravizados. As imagens das vestimentas encontram-se, aqui, na condição de um recurso inesgotável para tornar visíveis as necessidades de distinção e de poder (CUSTÓDIO, 2015). Um olhar demorado sobre a imagem, que mostra aqueles indivíduos cristalizados em suas poses, diversos em seus corpos e rostos, vestes e marcas, exibe diferenças contrastantes no cotidiano de cada um, em nível social e de trabalho. As vestimentas funcionam como uma máscara, constituindo próximos e distantes, fazendo com que separemos não somente o proprietário, como também aqueles homens escravizados. Uma série de traços e de marcas de diferenças que se acentuam através de suas vestes, modulando e produzindo sujeitos. A forma claramente distinta como cada indivíduo se veste, apesar de haver um padrão, aponta para singularidades e diferenças de expressão, gestos e outras características. No nosso caso, é coerente pressupor que, a cada vestimenta, correspondam a modos e condições escravas diferentes. Em se tratando da fotografia de Militão, é produzido aí como sujeitos, o "dono do retrato" e dos escravos descalçados cujos pés visíveis destacam uma das marcas da escravidão passíveis de escravos identificados no Rio de Janeiro do final do século XIX. ${ }^{2} \mathrm{O}$ toque direto ao chão, em contraponto com as botinas calçadas pelo proprietário à frente, instalam uma peça em uma rede de diferenciações entre as pessoas ali 
visualizadas. Essa rede, no entanto, não pode ficar reduzida ao binarismo Senhor versus Escravo, pois, se olharmos para o vestuário e o penteado do escravo que usa uma espécie de colete e que está à esquerda do proprietário, veremos que, sob essa ótica, alguns fracos podem se tornar fortes, alguns fortes podem se tornar fracos. Novas oposições, novas clivagens, novas distribuições conduzem-nos a descrever um novo cálculo nas relações de força (FOUCAULT, 2005a). A categoria monolítica "escravo", sustentada, muitas vezes, por determinismos socioeconômicos, cai por terra quando nos sugere diferenças e, possivelmente, hierarquias entre estes a ponto de definir os lugares ocupados pelos que estão próximos do seu dono e pelos que estão distantes dele, pelos que empunham objetos e pelos que não os empunham, pelos que se dão a ver de uma forma ou de outra. Exerciam poderes os escravos próximos ao proprietário? Trata-se de uma rede de diferenciações que, longe de buscar uma verdade sobre o acontecimento, encena quase uma peça, transfigura em personagens pessoas que, não fossem a captura fotográfica e o "dizer" de historiadores, não teriam jamais existido. A fotografia constitui o que Delaporte (2007), em uma análise de fotografias da França do século XIX, chamou de um "lugar singular", a invenção de um teatro, a "busca que inquieta, surpreendente e desconcertante a quem as observa" e, para penetrá-las, "há a necessidade de uma direção, caminhos, uma legenda" (DELAPORTE, 2007, p. 227-228). A sintaxe de que fala Foucault (200ob) sugere a imanência no dispositivo historiográfico que possibilita o encontro entre o registro fotográfico e a interpretação empreendida, a qual não resgata sujeitos, mas os constitui, os produz, visualmente, inventa-os. A invenção do passado, sob a ótica de Albuquerque Júnior (2007), é um caminho incontornável para aqueles/as que se propõem a analisar imagens, "pensar o outro no tempo do nosso próprio pensamento" (FOUCAULT, 2000a, p. 14) e, anacronicamente, fazer emergir, a partir do presente, um fosso incansavelmente cavado chamado de passado.

\section{Uma dimensão "menor" da imagem fotográfica}

Mas vamos criar outras telas e inventar outras histórias a partir de outros detalhes. Às margens, agora! Na extrema direita, uma personagem poderia passar despercebida para um observador desavisado. Eis uma dimensão "menor" da imagem fotográfica, indefinível, desestabilizada, desfocada. Uma dimensão que produz um "novo" de "dentro"; um lugar que 
produz a possibilidade do novo; um forasteiro de dentro com práticas que nos levam a novos agenciamentos, a novas conexões rizomáticas, em alusão ao conceito de "literatura menor", de Deleuze (1977). Que interesse haveria em falar sobre uma pessoa a qual, provavelmente, é um escravo que não alcançou a nitidez esperada em uma imagem fotográfica? Como analisar o borrão que estragou definitivamente o investimento feito pelo proprietário na imagem fotográfica? Distante, estaria esse escravo investido de menos poder, restando-lhe apenas apanhar, apanhar, apanhar?

A prática visual de desobediência visível na imagem fotográfica é uma prática social por meio da qual essa personagem é constituída como um sujeito da resistência, um sujeito do descaso com as regras possivelmente externalizadas inúmeras vezes para todos/as que eram submetidos/as a um processo de registro fotográfico. Assim, a prática visual de roubar a cena, transgredir a harmonia e a nitidez da imagem fotográfica, dentro de uma análise da imagem sobre o possível, constituem esse como sujeito do abalo à ordem escrava a ser eternizada pela produção imagética. Indefinível, a prática de desarmonizar a imagem desestabiliza a ordem e institui um lugar desterritorializado de um sujeito. Sujeito que abjura os rituais de produção de signos que a fotografia propiciava. Um sujeito constituído como expressão da luta dos negros contra a escravidão e que escolhe não amarrar a cara, mas esconder-se atrás de suas mãos, usar o seu próprio corpo como refúgio, já que não poderia aquilombar-se naquele momento.

Não há como negar, portanto, que o poder, conforme Foucault, só se exerce sobre "sujeitos individuais ou coletivos que têm diante de si um campo de possibilidades em que diversas condutas, diversas reações e diversos modos de comportamento podem acontecer" (FOUCAULT, 2010, p. 289). Em outras palavras, "a liberdade aparecerá como condição de existência do poder" (FOUCAULT, 2010, p. 289), pois o poder se exerce de ambos os lados, tanto de quem exerce quando do lado daquele sobre quem o poder é exercido, pois tanto proprietário quanto escravos expressam um assujeitamento, compreendido como "resposta individual à interpelação do social que cria as identidades e a identificação a um grupo, definindo sua inserção no espaço societal" (NAVARRO-SWAIN, 200o, p. 54). É um espaço onde os escravos praticam um tipo de liberdade, negociada talvez e, diferentemente, exercem um tipo de poder, não necessariamente voltado para oprimir o proprietário, mas sim estabelecer diferenças entre os mes- 
mos e fomentar uma cara amarrada, de zangado, do seu Senhor. Resistências às técnicas de assujeitamento? Uma prática libertária de resistência aos efeitos do poder, do controle e da dominação?

Possivelmente, a prática visual do escravo desobediente o constitui como sujeito cuja subjetividade produz uma expressão visual não de medo, mas certa liberdade, certa coragem de se arriscar e adotar uma tática de se esconder dentro da própria imagem fotográfica. Uma prática visual entre o visível e o invisível que, em uma perspectiva que talvez ponha em questão os mecanismos de dominação do visível, compreendidos como lugares de "domínio do poder e do controle" de que fala Meneses (2005, p. 36) ao ser objeto das "prescrições culturais e sociais" que normatizam visibilidades e invisibilidades (MENESES, 2005, p. 36).

Em suma, uma prática visual por meio da qual a dimensão "menor" da imagem fotográfica (DELEUZE, 1977) é operada como uma expressão visual de si (SANT'ANNA, 2013), como prática de produção e invenção, visualizável, de subjetividades diferentes. O escravo localizado à extrema direita se toca e, no movimento do seu toque, borra e se esconde, diferentemente da escolha dos outros, que permanecem imóveis e distantes do calor da pele, a não ser pelos pés em contato com a frieza do chão. Trata-se de uma prática que aciona princípios do "cuidado de si", povoada por exercícios como o cuidado com a disposição e exibição dos corpos, com a ausência e a presença de gestos extravagantes, com a ausência de toques entre uns e outros que, no entanto, não nos revelam uma solidão, mas o caráter social da prática do "cuidado de si" (FOUCAULT, 2005b, p. 57). Uma prática do "cuidado de si" como "uma prática da inconformidade" (FERRARI; ALMEIDA; DINALI, 2010, p. 118). A fotografia a ser registrada, munida de seu processo tecnológico visual, com suas técnicas e estratégias de normatização das condutas consigo, e com os outros, produz uma imagem "menor", aqui descrita como uma imagem incorporal, uma imagem desterritorializada, uma imagem que funciona como uma "expressão visual de si" (SANT'ANNA, 2013), ao produzir aquilo que possibilitamos ser visualizável, mas que também possibilitava a transgressão a fim de expressar subjetividades transgressivas possíveis.

O escravo que borrou e se escondeu no próprio corpo e na própria imagem mostra-nos uma dimensão "menor" da fotografia, compreendida como um lugar onde não são territorializadas as estabilidades e as harmonias. Mas um lugar 
desterritorializado, criativo, inconformável. Um lugar menor atribuído à imagem fotográfica, a qual não é uma representação da realidade, mas uma invenção. Trata-se de uma invenção da rede de sentidos possíveis no contexto específico em que a prática visual de esconder-se constitui, em uma rede de possibilidades, um sujeito rebelde, no campo dos possíveis jogos de poder e das conexões rizomáticas, ali desenhados, passíveis de serem mapeados na análise aqui empreendida sobre a imagem fotográfica. Desafia-nos tal perspectiva que recusa a dimensão mimética, representacional ou mesmo ilustrativa da fotografia, não a tomando como um documento que possibilitasse aos historiadores representar o passado. A prática visual de se esconder na própria fotografia abriga um regime de sentidos que não nos permite etiquetar a imagem fotográfica como representação, caso a tomemos como uma apresentação visual do social. E enquanto um regime de sentidos, a imagem fotográfica não é uma representação da escravidão. A fotografia não é um signo de recognição do passado. Assim, tratemo-la como um regime de sentidos que expressa, que fabrica e que inventa noções múltiplas de escravidão.

Enquanto imagem "menor" e apresentação visual através de um regime de sentidos, a prática visual de se esconder e constituir um sujeito escravo rebelde na imagem fotográfica não é uma representação à espera da descortinação de seus sentidos, suas causas descobertas e nem as intenções reveladas de quem a produziu. A "trama de visibilidades" (FISCHER, 2012, p. 136) da análise emanada suscita-nos teias rizomáticas possíveis, talvez infinitas, re-arranjadas em "uma unidade dessa multiplicidade, um todo desses fragmentos", de que fala Rouillé (2009, p. 104). Uma trama que encena práticas e exercícios de poderes diferentes - uma prática de enrijecer os músculos da face que constitui um sujeito homem zangado, e uma prática de liberar os braços esquivando o rosto e o corpo da visibilidade que constitui o lugar do homem rebelde - construídos no processo de desconstrução da própria imagem, na direção da produção de novas visibilidades. Abordagem esta que vai ao encontro das reflexões Rouillé (2009, p. 36, grifo do autor), para quem

a fotografia é máquina para, em vez de representar, captar. Captar forças, movimentos, intensidades, densidades, visíveis ou não; e não para representar o real, porém para produzir e reproduzir o que é passível de ser visível (não o visível). 
As novas visibilidades têm suas próprias regras, suas próprias leis e estão cravadas em uma ordem visual, compreendida como uma rede de visibilidades, como aquilo que é possível ver e dar-se a ver em determinado grupo social, em determinado recorte temporal. $\mathrm{O}$ visual é aquilo que Meneses (2005, p. 35) chamou de iconosfera, como um "conjunto de imagens-guia de um grupo social ou de uma sociedade num dado momento e com o qual ela interage”. Em outro momento, o autor definiu a visualidade como "conjunto de discursos e práticas constitutivas das distintas formas da experiência visual em circunstâncias historicamente específicas” (MENESES, 2003, p. 28). Enquanto discurso, na acepção foucaultiana, a visualidade, como imagens que nos investem e passam a ser nossas e a constituir as nossas subjetividades, são práticas as quais formam os objetos que visualizam, no caso aqui, os sujeitos/objetos que são visualizados. $\mathrm{O}$ visual, tomado aqui como um saber que produz visibilidades, como um dispositivo de visibilidades (DELEUZE, 2006, p. 6o), expressando, deste modo, relações sociais por meio das quais os sujeitos são inconcebíveis fora delas.

A operação analítica não é, portanto, nada além de tornar o visível visível e descrever a condição visualizável do visual. Longe de seguir receitas, uma arqueologia da visualidade aqui se ancora em uma analítica a ser fabricada e construída. Daí tomar a fotografia como um mapa é também não dominar todos os caminhos, e abrir a possibilidade de novas visibilidades, de uma rota a ser explorada e construída, haja vista que entre o olhar através do visor, na iminência de realizar o disparo fotográfico, e a imagem fotográfica resultante, há uma fração de segundos nebulosos - haja vista a opção de reduzir a velocidade do obturador - e sombrios, que designa e produz a imagem fotográfica. Assim, como não é a teoria que conduz à análise, não é a luz que prega a imagem à superfície (o que sustenta a aderência entre o referente e a imagem), mas é a analítica que abre possibilidades de leitura, do mesmo modo que ocorre com a escuridão, o blecaute proporcionado pela aparição da cortina escura, que distancia para sempre a imagem fotográfica resultante do processo e o quadro da realidade, anterior ao disparo, que o sujeito fotógrafo teria visto. A analítica, imanente às fontes empíricas escolhidas, se transforma em uma criação de conceitos e a imagem fotográfica passa a ser uma nova elaboração da realidade, uma invenção, um mapa sujeito à criatividade do fotógrafo e do analista. Na referida análise, pudemos percorrer pelas imagens que nos dão a criar 
uma possível cena da escravidão no Brasil, provida de relações e de processos de constituição de sujeitos. A fotografia deste modo, não representa, mas, ao operar suas dimensões "menores", não estáveis, desestabilizadas, desterritorializadas, cria e inventa, expressa.

Ancorados no regime da fotografia-expressão, alargamos os limites da fotografia-documento e construímos, na aventura, que é o exercício da arqueologia da visualidade, um acontecimento. A fotografia, por meio da operação com as ferramentas analíticas, exprime um acontecimento e não o representa. Ela é mais incorporal do que corporal, pois nega corpos, $a$ priori. E sugere "imagens de imagens" ao realizar uma "perda do elo com o mundo" (ROUILLÉ, 2009, p. 144). Trata-se de expressões desenhadas pela disposição das imagens dos corpos e dos incorpóreos, pela relação entre elas, pelas imagens das vestimentas, pelas imagens dos gestos e dos modelos de cabelo, pelas imagens que não se tornaram imagens, pela estética da existência de imagens. Imagens e imagens. Relações entre imagens sugerem-nos que "a fotografia não remete às coisas, mas à espiral infinita, a outras imagens"; "ao mundo das coisas sucede o das imagens, e as próprias imagens tendem a tornar-se mundo" (ROUILLÉ, 2009, p. 145). A série infinita de imagens que se interpõem entre o real e a imagem, invisíveis e operantes, de que fala Rouillé (2009), mostra-nos um mapa de possibilidades do passado.

Empreender uma arqueologia da visualidade, e também do visual, é operar uma metodologia nômade, sem receituários, é condição de sobrevivência, já que um conceito, por mais que seja sofisticado teoricamente, e construído muitas vezes para análise de realidades outras, exige-nos fissuras e suturas, imanentes e incontornáveis à luz do material empírico investigado. E a expectativa é a de que o conceito de imagem fotográfica como expressão visual de si seja uma nova sintaxe, ao invés de um neologismo (MACHADO, 2009, p. 206), onde funcionaria com "um todo fragmentado, uma multiplicidade de componentes, eles mesmos conceituais, heterogêneos, mas inseparáveis, intrinsecamente relacionados, agrupados em zonas de vizinhança ou de indiscernibilidade" (DELEUZE apud MACHADO, 2009, p. 314).

A imagem fotográfica, como possibilidade de expressar práticas visuais inscritas do regime da escravidão no século XIX, é um "acontecimento visual" no qual as várias leituras admissíveis sobre a fonte nos apontam para uma história visual do possível para além de uma história das evidências 
ou uma história das representações. Nessa história visual do possível, a história das imagens "menores" das fotografias, novas visibilidades são visualizadas, construídas, inventadas. Trata-se de um conceito compreendido em uma perspectiva de abordagem teórica, aberta e desprovida de uma definição estável. É nessa perspectiva que no programa da fotografia-expressão, "as visibilidades não se extraem diretamente das coisas" (ROUILLÉ, 2009, p. 163), mas o exercício a ser feito requer que se considere o acontecimento como um evento construído pela análise da imagem fotográfica. Quer dizer, construído em seu processo de desconstrução; emergente, na qualidade de evento, sem estar desvencilhado dos procedimentos que estabelecem imagens aceitáveis/válidas. O evento real aqui não é uma condição existente $a$ priori, mas é transformado em expressão com a fotografia. A prática de borrar e esconder-se na imagem constitutiva da posição de sujeito rebelde é uma construção visual do social, à luz da criação de analistas da cultura visual, no regime da fotografia-expressão de que fala Rouillé, que inventa novas visibilidades.

Analíticos, nosso trabalho dos investigadores de cultura visual e arqueólogos de visualidades é também de criadores, ao não separar a materialidade da realidade testemunhada no documento e na ficção, pois, conforme Rancière nos sugere, $o$ testemunho e a ficção abrangem "um mesmo regime de sentido" (RANCIÈRE, 2009, p. 57) com efeitos de real que nos possibilitam forjar mapas do visível (RANCIÈRE, 2009, p. 59). Mapas de subjetividade e conexões rizomáticas constituídos como expressão visual de si. Mapas com doses de indefinição, tecidos em andamento, imanente à análise. Expressão no sentido de estabelecer uma forma de pensamento, e não a pretensão de representar. Expressão como a busca a habilitar uma operação analítica a partir do objeto cuja potência, modesta, é criar e investigar o passado e fazer emergir sentidos, que não existem fora dos regimes que o expressam.

São estas algumas das inspirações nas quais ancoramos a nossa abordagem. Longe de tomá-las como receituário metodológico, ou simplesmente metodologia, propomos uma incursão de possibilidades que nos remetem aos estudos foucaultianos/deleuzianos, na busca por testar estratégias de assalto, marcadas por uma invasão subjetiva e por escolhas diante do empírico, capazes de nos fazer sustentar, enquanto arqueólogos de visualidades, uma leitura possível de uma expressão da cultura visual, dentre outras também cabíveis. O recurso aqui voltado para a abordagem foucaultiana/deleu- 
ziana da prática de esconder-se na imagem e constituir um sujeito insurgente exigiu-nos que fizéssemos a fundição de conceitos e a fabricação de novas armas. Um procedimento passível também de ser pensado como crítico já que é forjado no movimento de adquirir e refutar componentes, transformável quando mergulhado em um novo sistema de pensamento (DELEUZE, 2010). Essa operação foi nomeada por Deleuze como "plano de imanência", por se tratar de um campo fluido onde os conceitos inventados são exercício de uma bricolagem, um "aproveitamento de coisas usadas e adaptadas", um assalto a sistemas de pensamento, uma relação entre pensadores.

Uma arqueologia da visualidade pensada e operada como uma caixa de ferramentas com instrumentos de trabalho que não estão prontos, mas são forjados concomitantemente ao movimento de manuseá-los, testá-los, estabelecê-los. Eis uma operação menos contemplativa a conceitos já estabelecidos, mas voltada para, artesanalmente, aglutinar "pedaços ou componentes vindos de outros conceitos, que respondiam a outros problemas e supunham outros planos". A expressão visual da prática de borrar e esconder-se na imagem e constituir a posição de um sujeito amotinado é uma expressão visual de uma subjetividade singular e diferente como novo corte, novos contornos, retalhado (DELEUZE; GUATARRI, 2010). Isso porque o exercício eclético, aqui, a fazer colagens conceituais a partir de Foucault, Deleuze, Rouillé, Delaporte, Navarro-Swain, não é o de importação de idéias, mas o de cortar, recortar, e criar algo novo.

Longe de sermos submetidos a um poder pastoral oriundo de teorias de filósofos/historiadores, enquanto arqueólogos de visualidades, preferimos subverter conceitos, trair sistemas, destruir organismos. Uma criação profanadora, porém, sob controle, com o trabalho em arquivos, na busca por, segundo Salomon (2011b, p. o8), "transformá-los em objeto de interrogação histórica, deslocá-los das sombras que o poder lhes reservou, dá-los à luz do dia do conhecimento". Não fazer dos arquivos visuais objetos de depósito dos museus, cujo regime "transforma todos os modos de ser da história e todas as formas de arte em manifestação cultural, em manifestação do espírito da comunidade" (SALOMON, 2011a, p. 30), mas tratar a imagem fotográfica como arquivo na perspectiva de tomá-la como atravessada por saberes. Isso porque, continuando com o autor, "há, por outro lado, algum saber dos arquivos, algum saber próprio aos arquivos; os arquivos arquivam alguma coi- 
sa, portam traços de um saber com os quais a história tem o poder de fazer alguma coisa" (SALOMON, 2011b, p. 8). Investigar os saberes dos arquivos visuais é se defrontar com, além das visibilidades, as invisibilidades visíveis, as visibilidades invisíveis, e destacar o lugar, os esconderijos, na busca por analisar os arquivos do passado, não para buscar o real re-apresentado, sem tentar representá-lo, mas para inventar, criar o passado, dar um efeito de sentido. Submeter as verdades a um julgamento, e no lugar das verdades, dispor um vazio. Nada além do que uma composição aberta, não terminada! Das fotografias, destacar (in)visibilidades e imagens "menores", encontrar esconderijos, inconformidades. Dos arquivos, tecer uma vida criativa, criar ficções e estéticas libertárias, encenar teatros, construir visualidades.

\section{NOTAS}

'Optamos por operar com o conceito de "sentido" ao invés do conceito de "significado". Enquanto este é circunscrito ao campo da lingüística e demanda sempre um referente corpóreo, o termo sentido, em sua acepção deleuziana, é compreendido como elemento fundamental do pensamento, algo que, apesar de não possuir existência concreta, pertence ao mundo, está entre os incorporais, é um acontecimento que pressupõe sempre relações entre corpos. Segundo Deleuze, os sentidos são mais flexíveis do que os significados, não são intrínseco às coisas, possuem existência múltipla. Sobre o assunto, consultar: DELEUZE, Gilles. Lógica do sentido. São Paulo: Perspectiva, 1982.

${ }^{2}$ Sobre o assunto consultar: SCHWARCZ, Lilia Moritz. Retrato em Branco e Negro. Jornais, escravos e cidadãos em São Paulo no final do século XIX. São Paulo: Companhia das Letras, 2001. KARASCH, Mary C. A vida dos escravos no Rio de Janeiro: 1808-1850. São Paulo: Companhia da Letras, 2000.

\section{Referências}

AGAMBEN, Giorgio. O que é um dispositivo? In: AGAMBEN, Giorgio. O que é o contemporâneo? E outros ensaios. Chapecó, SC: Argos, 2009.

ALBUQUERQUE JÚNIOR, Durval Muniz. História: a arte de inventar o passado. Ensaios de Teoria da História. Bauru, SP: EDUSC, 2007.

ALENCASTRO, Luiz Felipe de. Vida Privada e Ordem Privada no Império. In: História da Vida Privada no Brasil. Império: a corte e a modernidade nacional. São Paulo: Companhia das Letras, 2002.

BARTHES, Roland. A Câmara Clara: notas sobre fotografia. Rio de Janeiro: Nova Fronteira, 1984. 
CUSTÓDIO, Ana Carolina de Santana. Vestir e marcar: a construção visual da vestimenta das mulheres escravizadas no Brasil Imperial - Século XIX. 2015. 172 f. Dissertação (Mestrado em Arte e Cultura Visual) - Faculdade de Artes Visuais, Universidade Federal de Goiás, Goiânia. 2015.

DELAPORTE, François. Anatomía de las pasiones. Barranquilla, Colômbia: Ediciones Uninorte, 2007.

DELEUZE, Gilles; GUATARRI, Félix. O que é filosofia? 3. ed. Rio de Janeiro: Ed. 34, 2010.

. Mil Platôs: capitalismo e esquizofrenia. 2. ed. v. o1.. São Paulo: Ed. 34, 2011.

DELEUZE, Gilles. Kafka: por uma literatura menor. Rio de Janeiro: Imago, 1977.

. Diferença e Repetição. Lisboa: Relógio d'Água, 2000. Foucault. São Paulo: Brasiliense, 2006.

DIKOVITSKAYA, Margaret. Visual Culture: the study of the visual after the cultural turn. Cambridge: MIT Press, 2006. FERRARI, Anderson; ALMEIDA, Marcos Adriano de; DINALI, Wescley. Teoria e Subjetividades queer: poder, resistência e corpo. In: CLARETO, Sônia Maria; FERRARI, Anderson (Org.). Foucault, Deleuze E Educação. Juiz de Fora: Ed. UFJF, 2010.

FISCHER, Rosa Maria Bueno. Um pensador na linha feiticeira. In: Trabalhar com Foucault: arqueologia de uma paixão. Belo Horizonte: Autêntica, 2012. (Coleção Estudos Foucaultianos).

FLUSSER, Vilém. Filosofia da Caixa Preta: Ensaios para uma futura filosofia da fotografia. Rio de Janeiro: Relume Dumará, 2002, (Coleção Conexões).

FOUCAULT, Michel. A arqueologia do saber. Tradução Luiz Felipe Baeta Neves. 6. ed. Rio de Janeiro: Forense Universitária, 200oa.

. As Palavras e as Coisas: uma arqueologia das Ciências Humanas. São Paulo: Martins Fontes, 2ooob.

. Aula de 18 de Fevereiro de 1976. In: FOUCAULT, Michel. Em Defesa da Sociedade. São Paulo: Martins Fontes, 2005a.

. História da Sexualidade. O cuidado de si. Tradução: Maria Theresa da C. Albuquerque. Rio de Janeiro: Edições Graal, 2005b.

. Microfísica do Poder. Organização, introdução e revisão técnica de Roberto Machado. 16. ed. Rio de Janeiro: Edições Graal, 2001.

..__ O Sujeito e o Poder. In: DREYFUS, H; RABINOW, 
Paul. Michel Foucault: uma trajetória filosófica. Para além do estruturalismo e da hermenêutica. 2. ed. Rio de Janeiro: Forense Universitária, 2010.

HUTCHEON, Linda. Poética do Pós-Modernismo: história, ficção, teoria. Tradução Ricardo Cruz. Rio de Janeiro: Imago, 1991.

KNAUSS, Paulo. O desafio de fazer história com imagens: arte e cultura visual. ArtCultura, Uberlândia, v. 8, n. 12, p. 97-115, jan./jun., 2006.

KOUTSOUKOS, Sandra Sofia Machado. No estúdio fotográfico: representação de negros livres, forros e escravos no Brasil da segunda metade do século XIX. 2006. $382 \mathrm{f}$. Tese (Doutorado em Multimeios) - Instituto de Artes, Universidade Estadual de Campinas, Campinas, SP, 2006.

MACHADO, Roberto. Deleuze: a arte e a filosofia. Rio de Janeiro: Zahar, 2009.

MATTOSO, Kátia de Queirós. Ser escravo no Brasil. São Paulo: Brasiliense, 2001.

MENESES, Ulpiano T Bezerra. Fontes Visuais, cultura visual, história visual. Balanço provisório, propostas cautelares. Revista Brasileira de História. São Paulo, v. 23, n. 45, p. 1136, 2003.

. Rumo a uma "História Visual". In: MARTINS, José de Souza; ECKERT, Cornelia; NOVAES, Sylvia, Caiuby (Org.). O imaginário e o poético nas ciências sociais. Bauru, São Paulo: Edusc, 2005.

MITCHELL, W. J. T. Showing seeing: a critique of visual culture. Journal of Visual Culture. v. 1, n. 2, p. 165-181, 2002.

NAVARRO- SWAIN, Tânia. O que é lesbianismo?(on-line). São Paulo: Ed. Brasiliense, 2000.

. Os limites discursivos da história: imposição de sentidos. In: Labrys. Estudos Feministas. Jan./Jun. 2006. Disponível em: <http://www.tanianavarroswain.com.br/labrys/labrys9/libre/anahita.htm>. Acesso em: 28 ago. 2013. RANCIÈRE, Jacques. A Partilha do Sensível: estética e política. 2. ed. São Paulo: EXO experimental; Editora 34, 2009.

ROUILLÉ, André. A fotografia entre documento e arte contemporânea. São Paulo: Senac, 2009.

SALOMON, Marlon. A Danação do Arquivo: ensaio sobre a história e a arte das políticas culturais. In: . Saber dos arquivos. Goiânia: Ricochete, 2011 . Saber dos Arquivos. In: . Saber dos arquivos. Goiânia: Ricochete, 2011b.

SANT'ANNA, Thiago F. A Fotografia como Expressão de si: 
uma história visual do possível. In: MONTEIRO, Rosana H.; ROCHA, Cleomar (Org.). Anais do VI Seminário Nacional de Pesquisa em Arte e Cultura Visual. Goiânia: UFG, FAV, 2013.

SOUZA, Gilda de Mello e. Espírito das roupas: a moda no século dezenove. São Paulo: Companhia das Letras, 1987.

VEIGA-NETO, Alfredo. Foucault E Educação. 2. ed. Belo Horizonte: Autêntica, 2004. (Coleção Pensadores \& Educação).

Recebido em: 17/04/2016

Aceito em: 22/05/2017

\section{THIAGO F. SANT'ANNA}

thiagof.santanna@yahoo.com.br

Thiago F. Sant'Anna é Historiador, também possui graduação em Serviço Social, pela Pontifícia Universidade Católica de Goiás. Doutor em História pela Universidade de Brasília, possui Pós-Doutorado em Arte e Cultura Visual pelo Programa de Pós-Graduação em Artes e Cultura Visual/ Faculdade de Artes Visuais/ Universidade Federal de Goiás, onde atua como docente adjunto permanente. Atualmente, é professor do curso de Arquitetura e Urbanismo da Universidade Federal de Goiás/ Regional Cidade de Goiás.

\section{ANA CAROLINA CUSTÓDIO}

karolcustodio@live.com

Mestre em Arte e Cultura Visual da Faculdade de Artes Visuais da Universidade Federal de Goiás e Bacharel em Design de Moda, também pela Faculdade de Artes Visuais - UFG. Realizou docência no curso de Design de Moda FAV/UFG nas disciplinas de Desenho de Moda. Atua como professora substituta no curso de Design de Moda da Faculdade de Artes Visuais/ Universidade Federal de Goiás. 